\title{
Transnational companies and production global networks
}

\author{
Valentina Golea, University Politehnica of Bucharest \\ Nicoleta Niculescu*, University Politehnica of Bucharest \\ Dragoş Filip Niculescu, Economist
}

\begin{abstract}
Internationalizing a company is an objective process. The historical reality shows that, while developing, the company tends to exceed its local, national and regional limits of business environment, in order to expand its activity into the global economic space, whose formatting is possible through the very company's movement towards exterior. This process is based on the imminent expansionism of the market forces, their tendencies to invade the environment "unmarketedly", and to include it in an economic system based on the market mechanism. Companies involve themselves in the international production because they have a specific competitive advantage which is best exploited in this way. The advantage can consist in a product or in a brevetted technique, but it may also include management techniques or such as: company's or its employee's qualification and expertise.
\end{abstract}

\section{Keywords}

international production, production global networks, transnational company, global competition, business organization, innovation, corporatist strategies

JEL Codes: F13, F23

\section{Introduction}

In spite of certain advantages, companies are not obliged to produce abroad; foreign markets can be supplied through exports or through offering under-license technologies by the foreign producers; or the production process may be subcontracted to some independent companies, possibly authorized to use the company's technology. However, the development of the production global networks necessarily involves the strategic organization of the transnational transactions within companies or company groups, and not through the market mechanism. Despite the fact that the economic globalization is often understood as being only the spread of global markets, the development of the transnational societies and of the production global networks represents something very different: the organization of the more transnational production and distribution within companies and between them, and not through markets. The international markets are not perfect: if they were perfect, the transnational societies and the production global networks would not exist. Therefore, the costs determined by the transnational companies' activities are considerably

\footnotetext{
* The paper is carried out within the Sectorial Operational Program for Human Resources Development for 2007-2013, “ Invest in people!” cofinanced by European Social Fund
} 
lower if these companies organize the economic activity within the company or through company networks and not through market relations.

The restrictions on the international trade, as well as the transport costs stimulate companies to take positions and to produce abroad, instead to export to foreign markets. The transnational societies can organize production at international level in order to make use of the abroad low costs for certain stages of the production process. But the strategic advantages of organizing the international production within the company, not in favor of the independent producers' sourcing, are given by two factors: the former, prevention of spreading any technological advantage of the corporation to the potential competitors; the latter, as long as the competitive advantage of a transnational company does not lie in only encoded knowledge, but in a series of tacit knowledge and expertise within the company, the optimum way to exploit it, is the intra company production abroad and not the under licensed production or subcontracting abroad.

\section{Global Competition and Business Organization}

The transnational companies have developed lately because they have exploited their competitive advantages at international level. In some cases, these advantages come from ladder-economies, from superior management techniques and/or from world sales networks. But the main source of the transnational companies' competitive advantage has been technological innovation. The transnational companies tend to be the most innovative companies and they are strongly represented in the technologically most dynamic industries. They are responsible for the most private expenses for research and development. Moreover, the technological innovation has helped the process of "severing the value chain", through which a production process can be severed and distributed all over the world. Thus, the transnational societies' expansion reflects both their capacity to innovate and their capacity to exploit it at international kevel.

Nonetheless, despite the fact that transnational companies dominate the production of many goods and services and their global distribution, their technological and organization advantages have not made them undefeatable regarding competition. In a series of sectors, from electronics to clothes, some small and medium-size enterprises possess the capacity of continual innovation and flexibility, fact that creates a "hyper competition" environment in which only renowned transnational societies stand at defensive positions. Therefore, the competitive advantages do not lie on only products and technologies, but depend on the speed at which the innovation is produced and on the speed at which new products (styles, etc.) can be created and distributed.

This acceleration of the global competition has been mainly enhanced due to the revolution of "informatics". These factors have encouraged the growth of the trans-frontier production and distribution networks, being meant to the producer and to the buyer, so that small and medium-size enterprises could get in contact with the largest corporations, making networks capable of innovating and of adapting themselves continually.

While the technological innovation becomes more decisive for the competitive advantages of the transnational societies, there are greater entices for organizing production and distribution within the company or within geographically spread company networks that are conducted by transnational societies. J. Dunning sustains that this fact leads to a new situation, because the intra company transactions become more important compared with market transactions. There is a paradox here, because, the way the economic globalization has contributed to the global markets evolution, the business globalization has also encouraged the transactions' substitution on the market through intra companies' networks and between companies.

Although the level of the intra company trade is high, it seems to have remained stable as proportion of total trade for the past decade. But, as the trade has grown compared to the world's income, this tends to suggest a raise in the intra company trade reported to the world production. 
In spite of the fact that the individual transnational societies vary, regarding their capability to organize production and intra company trade, taken together, they supply the markets all over the world and produce from locations found on all the continents. Even if the individual transnational societies do not supply every national market or source from each country, their activities, taken together, have determined a structural evolution to a more intensive global competition due to the expansion of the production global systems.

Skeptics tend to doubt the existence of these modifications. They claim that even the largest transnational societies often develop the majority of their production, sales, actives, profits and research and development facilities in their origin country and conclude: "Global corporations are national companies with international operations". Other authors, especially M. Porter, accept the fact that transnational societies compete at a global level, but they sustain that transnational societies stand rooted in the economic and cultural system of their country; according to this concept, they extract their competitive advantage from the national base mainly, and they apply global strategies to face competition. J. Stopford and S. Strange, among others, claim that, although this concept highlights significant aspects in the postwar development of transnational societies, a national base becomes insufficient to maintain a corporatist competitive advantage. Along years, foreign companies have acquired their own technological advantages. Other sources of the competitive advantage, such as superior management techniques, spread themselves in time. Different authors - included P. Dicken, J. Dunning - sustain that transnational societies do not extract the competitive advantage only from intern base but they penetrate, more and more deeply, the world sources of competitive advantage, self-organizing their production at a global scale. Their capability to produce in a series of countries and to achieve competitive advantages generated in different locations, confers them a global vision and a global competitive advantage. In the hyper global concept of some authors, like D. Julius, K. Ohmae and R. Reich, transnational societies are "unbound", circulating rapidly between countries, transferring production and penetrating the sources of the national competitive advantage in order to maximize their profits, often in the detriment of a immobile work force.

\section{Organization Forms of Business Globalization}

For the last decades, the global organization of the production and distribution has been intensified within some fundamental industrial sectors. Transnational societies have had a central role in this evolution. Many European firms have developed their multinational production starting from their intern base, which is, on principle, valid for all Japanese manufacturers. The expansion abroad to avoid real or potential protectionism, have been a key-factor in the determination of the Japanese and other nationalities' hesitating companies to produce abroad, but the transnational societies have not expanded abroad only to ensure their access to markets: they have proceeded in this way in order to rationalize their corporate production process through transnational.

This fact outlines a central idea, transnational societies have proceeded at setting up transnational business networks including their branches, subcontractors, customers and other industrial companies. But these networks, directed by the manufacturer or the buyer, involve a certain degree of power and decision spreading, so that the classical representation of the transnational societies (and of the multinational production) as a hierarchy structure, vertically integrated, does not reflect the amazing diversity of the present organization forms. W. Ruigrok and R. Tulder offer a useful typology in order to classify the organization forms of the global production and distribution networks. Adapting their typology, we could identify two organization forms that represent the extremes of a spectrum: dispersed production with an intensive central control and dispersed production with a reduced central control. Practically, transnational societies (and global production networks) often lie somewhere between these two extremes. 
The geographically dispersed production found under reduced central control, refers to the transnational production systems in which the production units have a considerable amount of autonomy. Historically, this fact has meant producing on their own, it means that companies have placed factories abroad in order to serve local markets, without integrating these operations into the transnational production systems. This is not only a method to penetrate protected markets, as where request conditions vary considerably from one country to another one, there cannot be an efficient strategy for supplying foreign markets. Services, especially, are often offered at a local level, instead of maintaining a powerful central control and some transnational societies adopt much more diffused corporation management systems. In order to make the operations efficient abroad, these should be granted a larger autonomy, instead of being imposed a central control; the idea is valid especially for research and development divisions, and also for a larger sphere. In addition, in many sectors, the transnational societies have passed from direct property and control to using, in a larger measure, subcontractor relations with (formally) independent suppliers.

The geographically dispersed production found under powerful central control, determines the organization of the global-scale production process as a central level coordinated strategy. This is also the popular perception about huge transnational societies that control production networks all over the world, but the process does not necessarily take place through direct property on the branches abroad. This organization form is frequent, in a certain degree, in ore extraction industry and in agriculture. A part of the processing industry production assemblage is organized on a strict hierarchy production line, operating at transnational level. Also, it can be met in the services' sector: for example, the American firms appeal to data collecting offices in Central America and in the Carribean, and the European companies do the same, reaching Southern Asia. It is also available when transnational societies produce a good or a service at local level, still maintaining the central control over production and quality; for many internationally well-known goods and services, the commercial brand ( for example Benetton) is created as a constant quality guaranty all over the world.

Beside these distinct organization forms, global commuting and global focusing corporation strategies can be identified. The global commuting refers to the transnational societies' capability to commute their production between different locations at the international level as a response to the continually changing market conditions. The global focusing, on the contrary, refers to the corporate strategy to concentrate its production in a low number of places, considered to have the highest long term advantage. Many societies, which have a considerable number of subcontractors, have tried to rationalize their activity, developing more intensive relations with a lower number of subcontractors; by contrast, firms with a limited number of subcontractor relations, have tended to expand them. Both strategies are ideal types essentially, but they focus on strategic choices firms face as a reaction to global competition's challenges and opportunities.

\section{Conclusions}

Business globalization depends, therefore, on the innovation capability of the companies and on their ability to efficiently organize trans-frontier production and distribution networks with the help of the technology progress in communications and of the management techniques. If the multinational production were set up, as in the past, only to elude the commercial barriers, one would expect that its expansion should have been slowed down or even been reduced, because commercial restrictions and transport costs have diminished spectacularly. But it has continued, suggesting that commercial barriers do not explain, only themselves, the increase of the transnational production; firms' capability to innovate in technology and product fields, is essential.

Other sources of competitive advantage, such as superior management techniques, spread in time. A range of authors claim that, nowadays, transnational societies do not extract their 
competitive advantage, only based on their intern base, but they penetrate, more and more, the world sources of competitive advantage, therefore organizing their production at global scale. Their capability to produce in a series of countries and to achieve competitive advantages generated in different locations, confers them a global vision and a global competitive advantage.

\section{Bibliography}

1. Dicken, P, 1998, Global Shift (ediția a III-a), Londra, Chapman

2. Dunning, J, 1993, The Globalization of Business, Londra, Routledge

3. Golea, Valentina, 2008, Managementul afacerilor multinaționale, Ed. Bren

4. Hirst, P. şi Thompson, G, 1996, Globalization in Question: The International Economy and the Possibilities of Governance, Cambridge, Polity Press

5. Julius, D, 1990, Global Companies and Public Policy, Londra, Pinter

6. Mockler, R.,2001, Management strategic multinațional, Ed. Economică

7. Ohmae, K, 1990, The Borderless world, Londra, Collins

8. Porter, M, 1990, The Competitive Advantage of Nations, Londra, Macmillan

9. Reich, R., 1991, The Work of Nations: Preparing Ourselves for Twenty-First Century Capitalism", New York, Simon and Schuster

10. Ruigrok, W. şi Tulder, R, 1998, The Logic of International Restructuring, Londra, Routledge

11. Stopford, J. şi Strange , S, 1991, Rivals States, Rivals Firms: Competition for World Market Shares, Cambridge, Cambridge University Press 